\title{
Prasangka Sosial dan Efektivitas Komunikasi Antarkelompok
}

\author{
Ahmad Sihabudin dan Suwaib Amiruddin
}

ABSTRACT

\begin{abstract}
Baduy community is one of ethnics known as Isoated Custom Comunity (Komunitas Adat Terpencil). The research is a quantitative research, using survey methode.

The data was colected from sample of population. The research is aimed to describe the correlation and effect among variables by hypotesis test, called as explanatory research.

The result shows that social distance in Baduy Dalam Community deeply determines the effectivity of Ciboleger communication. It means, the farther social distance in Baduy Community is the less effective Ciboleger communication is. Discriminations in Baduy Dalam Community does not determine the communication effectiveness in Ciboleger Community. Social distance both in Baduy Dalam and Baduy Luar effects one to another in term of effective communication between them. Social distance in Baduy Dalam effects their communication with Baduy Luar. The farther social distance in Baduy Dalam is, the less effective the communication is. Discrimination in Baduy Dalam community deeply determines the communication effectiveness with Baduy Luar.
\end{abstract}

Kata kunci: masyarakat baduy, prasangka sosial, komunikasi antarkelompok

\section{Pendahuluan}

\subsection{Latar Belakang Masalah}

Indonesia merupakan suatu bangsa yang masyarakatnya majemuk. Kemajemukan itu terbentuk, antara lain, karena beragamnya latar belakang bangsa dalam hal suku, agama, ras, dan golongan (Koentjaranigrat, 1982:49). Ditinjau dari paradigma politik, kemajemukan bisa mengandung masalah, karena dapat menjadi pemicu lahirnya disintegrasi nasional. Sedangkan ditinjau dari paradigma keilmuan, kemajemukan bisa merupakan suatu lahan studi yang menarik, antara lain dapat menyelidiki pertanyaan dan jawaban tematis tentang : apa, mengapa, siapa, di mana, kapan, dan bagaimana terjadi hubungan atau interaksi dalam setiap kelompok masyarakat itu; telah, sedang, bakal terjadi. Semua konsep tersebut sebenarnya dapat dikaji secara ilmiah melalui sudut pandang ilmu antropologi, sosiologi, psikologi, psikologi-sosial, linguistik, maupun kajian interdisipliner, seperti ilmu komunikasi.

Semboyan Bhineka Tunggal Ika yang tertulis di lembar pita yang dicengkeram burung Garuda bukan hanya slogan belaka. Semboyan tersebut 
dipilih karena memang demikianlah kondisi bangsa ini. Perbedaan yang ada bukan menjadi penyebab pertentangan, namun seharusnya menjadi perekat dan penyatu segala perbedaan yang ada. Berbicara mengenai komunitas adat terpencil, memang tidak bisa terlepas dari beragamnya budaya yang ada di Indonesia. Masing-masing budaya memeliki keunikan tersendiri. Pertanyaannya adalah apakah kebudayaan yang ada tersebut dapat menjadi daya tarik bagi pariwisata, misalnya, atau memang dengan sengaja dijaga agar jangan sampai mendapatkan akses yang membuat mereka menjadi semakin pintar dan lambat laun akan meninggalkan budaya yang ada? Penulis mencoba menyoroti salah satu suku yang ada di Indonesia, yaitu suku Baduy.

Secara administratif, wilayah Baduy atau biasa pula disebut wilayah "Rawayan" atau wilayah "Kanekes", termasuk dalam desa Kanekes, kecamatan Leuwidamar, kabupaten Lebak, Provinsi Banten (dulu masuk wilayah Jawa Barat). Wilayah yang dihuni Orang Baduy ini berada pada kawasan pegunungan Kendeng yang juga sebagiannya merupakan hutan lindung. Wilayahnya berbukitbukit, dan pemukiman biasanya berada di wilayah lembah bukit, pada daerah-daerah datar dekat sumber air tanah atau sungai.

Wilayah Baduy sekarang memiliki luas 5.101,85 hektar, jauh lebih kecil dibandingkan dengan keadaan pada abad ke-18 yang terbentang mulai dari kecamatan Leuwidamar (sekarang) sampai ke Pantai Selatan. Batas desa seperti yang ada sekarang, dibuat pada permulaan abad ke-20, bersamaan dengan pembukaan perkebunan karet di desa Leuwidamar oleh pemerintah Hindia Belanda yang dilaksanakan oleh Patih Derus (Iskandar, 1992:21-23; Garna,1993:121-125).

Sebutan "Orang Baduy" atau Urang Baduy yang digunakan untuk kelompok masyarakat ini bukan berasal dari mereka sendiri. Penduduk wilayah Banten Selatan yang sudah beragama Islam, biasa menyebut masyarakat yang suka berpindah-pindah, seperti halnya orang Badawi di Arab, dengan sebutan "Baduy". Orang-orang Belanda seperti Hoevell, Jacobs, Meijer, Penning, Pleyte, Trcht, dan Geise, menyebut mereka badoe'i, badoej, badoewi, dan orang knekes seperti dikemukakan dalam laporan-laporannya. Sekitar tahun 1980-an, ketika KTP(kartu Tanda Penduduk) diberlakukan di sini, hampir tidak ada yang menolak dengan sebutan Orang Baduy. Walaupun, sebutan diri yang biasa mereka gunakan adalah Urang Kanekes, Urang Rawayan, Urang Tangtu (Baduy Dalam) dan Urang panamping (Baduy Luar). Nama "Baduy" mungkin diambil dari nama sungai Cibaduy dan nama gunung Baduy yang kebetulan berada di wilayah Baduy (Garna, 1993:120).

Masyarakat Baduy adalah salah satu etnik yang dapat dikatakan sebagai komunitas yang mengisolir diri, atau dalam istilah sekarang Komunitas Adat Terpencil sebagai pengganti istilah Masyarakat Terasing. Selanjutnya, istilah tersebut dikukuhkan dengan Surat Keputusan Presiden No 111 tahun 1999. Dalam Surat keputusan Presiden itu disebutkan bahwa Pengertian Komunitas Adat Terpencil adalah kelompok sosial budaya yang bersifat lokal dan terpencar serta kurang atau belum terlibat dalam jaringan dan pelayanan baik sosial, maupun ekonomi.

Secara umum, masyarakat Baduy terbagi menjadi tiga kelompok, yakni tangtu (pendahulu, cikal bakal, pokok); panamping (pinggir, buangan); dan dangka (rangka, kotor). Tangtu dan panamping berada di wilayah desa Kanekes, sedang dangka terdapat di luar desa Kanekes. Bila dilihat dari tingkat ketaatan pada adat, maka tangtu lebih tinggi dari panamping, dan panamping lebih tinggi dari dangka. Meski demikian, pengelompokan yang sering digunakan adalah tangtu merujuk pada masyarakat Baduy Dalam, sedangkan panamping dan dangka merujuk pada masyarakat Baduy Luar. Baduy Dalam (disebut juga Baduy Jero, Urang kajeroan) sebagai pemegang adat yang teguh, memiliki tiga kampung, yaitu (1) Cikeusik, disebut juga tangtu Pada Ageung, (2) Cibeo, disebut juga tangtu Parahiyangan, dan (3) Cikartawana, disebut juga tangtu Kujang. Ketiga kampung suci ini disebut juga sebagai telu tangtu (tiga tangtu).

Orang Baduy menganggap bahwa ketiga tangtu tersebut sebagai tanah larangan, yakni 
Terakreditasi Dirjen Dikti SK No. 56/DIKTI/Kep/2005

daerah yang dilindungi dan tidak sembarang orang dapat masuk dan berbuat sekehendaknya. Sedangkan Baduy Luar terdiri dari sekitar 50 kampung yang tersebar di sebelah barat, timur, dan utara dari Baduy Dalam. Di sebelah selatan, tidak ada pemukiman/kampung, kecuali Sasaka Domas tempat atau objek pemujaan yang dianggap paling suci bagi Orang Baduy (Danasasmita, 1986; Garna, 1993, Permana, 2001).

Masyarakat Baduy mengenal dua sistem pemerintahan, yakni sistem nasional dan sistem tradisional (adat). Dalam sistem nasional, masyarakat Baduy termasuk dalam wilayah desa Kanekes, kecamatan Leuwidamar, kabupaten Lebak, provinsi Banten. Desa Kanekes dipimpin oleh kepala desa yang disebut jaro pamarentah (awalnya disebut jaro warega, dan pada jaman kolonial disebut jaro gubernemen). Sedangkan, secara tradisional pemerintahan pada masyarakat Baduy bercorak kesukuan disebut kapuunan, karena puun merupakan pimpinan tertinggi. Ada tiga orang puun di wilayah Baduy, masing-masing puun Cikeusik, puun Cibeo, dan puun Cikartawana, yang merupakan "tritunggal". Para puun dibantu oleh jaro (pelaksana harian kapuunan), girang seurat (pemangku adat), baresan (keamanan), dan tangkesan (kepala dukun).

Di Baduy Luar, tidak ada puun, pemimpin tertinggi di sini dipegang oleh jaro (sebagai kepala kampung) beserta pembantu-pembantunya (Garna, 1993, Permana,2001).

Salah satu masalah yang selalu dihadapi oleh setiap masyarakat majemuk adalah komunikasi antaretnik. Seringkali hasil komunikasi antaretnik adalah munculnya perasaan kurang terbuka antaretnik, kurang empati, selalu berpikir negatif, kurang memberikan dukungan dan menjaga keseimbangan.

Penelitian ini difokuskan pada efektivitas komunikasi yang dialami oleh para komunikator dari setiap kelompok (Suku Baduy Luar - Suku Baduy Dalam- Masyarakat Ciboleger Lebak, dan Wisatawan) dengan para komunikan dari kelompok lain. Pesan-pesan prasangka sosial (stereotip, jarak sosial, dan sikap diskriminasi) dari para komunikator setiap kelompok mempengaruhi efektivitas komunikasi dengan para komunikan dari kelompok lain.

Perbedaan persepsi para komunikator dari setiap kelompok tentang pesan-pesan; stereotip, jarak sosial, sikap diskriminasi serta efektivitas komunikasinya pada para komunikan dari kelompok lain. Melihat variabel-variabel lain (variabel anteseden) yang memengaruhi persepsi para komunikator dari setiap kelompok terhadap pesan-pesan tentang; stereotip, jarak sosial, sikap diskriminasi serta efektivitas komunikasi pada para komunikan dari kelompok lain.

\subsection{Permasalahan Penelitian}

(1) Bagaimana efektivitas komunikasi yang dialami oleh para komunikator dari setiap kelompok (Suku Baduy Luar - Suku Baduy DalamMasyaraka Ciboleger Lebak dan Wisatawan) dengan para komunikan dari kelompok lain?

(2) Bagaimana pesan-pesan prasangka sosial (stereotip, jarak sosial, dan sikap diskriminasi) dari para komunikator setiap kelompok memengaruhi efektivitas komunikasi dengan para komunikan dari kelompok lain?

(3) Bagaimana perbedaan persepsi para komunikator dari setiap kelompok tentang pesan-pesan; stereotip, jarak sosial, sikap diskriminasi serta efektivitas komunikasinya pada para komunikan dari kelompok lain?

(4) Bagaimana variabel-variabel lain (variabel anteseden) mempengaruhi persepsi para komunikator dari setiap kelompok terhadap pesan-pesan tentang; stereotip, jarak sosial, sikap diskriminasi serta efektivitas komunikasi pada para komunikan dari kelompok lain?

\subsection{Tujuan Penelitian}

Tujuan penelitian ingin mengetahui:

(1) Efektivitas komunikasi yang dialami oleh para komunikator dari setiap kelompok (Suku Baduy Luar - Suku Baduy Dalam- Masyaraka Ciboleger Lebak dan Wisatawan) dengan para komunikan dari kelompok lain?

(2) Pesan-pesan prasangka sosial (stereotip, jarak 
sosial, dan sikap diskriminasi) dari para komunikator setiap kelompok memengaruhi efektivitas komunikasi dengan para komunikan dari kelompok lain?

(3) Perbedaan persepsi para komunikator dari setiap kelompok tentang pesan-pesan; stereotip, jarak sosial, sikap diskriminasi, serta efektivitas komunikasinya pada para komunikan dari kelompok lain?

(4) Variabel-variabel lain (variabel anteseden) memengaruhi persepsi para komunikator dari setiap kelompok terhadap pesan-pesan tentang; stereotip, jarak sosial, sikap diskriminasi serta efektivitas komunikasi pada para komunikan dari kelompok lain?

\subsection{Kegunaan Penelitian}

Penelitian ini berguna sebagai proses belajar dalam mengaplikasikan konsep-konsep teori dan model komunikasi dalam komunitas adat terpencil, yang didasarkan pada teori dan pengamatan (empirik). Tujuan penelitian ini sebagai berikut:

(1) Dari segi keilmuan, hasil penelitian ini diharapkan sebagai khazanah untuk memperkaya kajian ilmu komunikasi. Diharapkan adanya perluasan segi-segi teoretis komunikasi antarbudaya, dengan melahirkan dalil-dalil baru yang dapat menunjang penelitian sejenis pada masa yang akan datang.

(2) Dari segi praktis diharapkan bermanfaat untuk menangani masalah-masalah prasangka sosial yang terjadi, khususnya pada masyarakat Baduy, maupun masyarakat dalam kategori adat terpencil lainnya yang memiliki karakteristik yang sama dan menyusun kebijakan tentang pembangunan komunitas adat terpencil yang berorientasi kesejahteraan dan kelestarian adat dan lingkungan.

\section{Tinjauan Pustaka}

\subsection{Perspektif Etnosentris}

Perspektif etnosentrisme dari Graham Sumner (1906) memandang masyarakat sebagai proses interaksi. Etnosentrisme adalah sikap setiap etnik yang sangat terikat dan mempertahankan nilai kelompok etniknya sebagai yang terbaik dalam suatu masyarakat. Keterikatan itu memperkuat rasa kita (in group) dan berprasangka negatif terhadap rasa mereka (out group). Sumner yakin bahwa setiap etnik tanpa kecuali memiliki etnosentrsime, demikian kuatnya etnosentrisme, sehingga prasangka sosial yang mempengaruhi perilaku seseorang termasuk perilaku berkomunikasi.

Menurut DeVito (1998:157) kelompokkelompok yang hidup di tengah-tengah masyarakat dapat dikatakan sebagai sebuah subkultur dalam sebuah kultur yang lebih besar. Ini dapat didasarkan atas agama, wilayah geografis, pekerjaan, orientasi, afeksi, suku bangsa, kebangsaan, minat, kondisi hidup, dan sebagainya. Zastrow (1989:483), berpendapat setiap kelompok etnik merupakan himpunan manusia karena kesamaan ras, agama, asal usul bangsa atau kombinasi dari kategori-kategori itu. Kelompok ini mempunyai keterikatan etnik yang tinggi, melalui sikap etnosentrisme orang cenderung memandang norma dan nilai kelompok budayanya sebagai sesuatu yang absolut dan dapat digunakan sebagai standar untuk mengukur dan bertindak terhadap kebudayaan lain.

Asumsi teoretis itu, menjelaskan bahwa etnosentrisme sangat berperan membentuk prasangka sosial dalam mencapai efektivitas komunikasi antarkelompok. Konsep ini dapat dijadikan sebagai suatu paradigma untuk meneliti komunikasi anggota masyarakat dengan latar belakang kelompok yang beragam. Setiap masyarakat majemuk yang dilatarbelakangi oleh kebudayaan yang berbeda selalu mengahadapi masalah etnosentrisme. Perbedaan itu merupakan akibat dari perbedaan folkways yang dimiliki setiap masyarakat yang kemudian dapat mencuat dalam bentuk perpecahan yang mengarah ke disintegrasi sosial. Untuk mencegah terjadinya disintegrasi, maka peranan komunikasi (antarpribadi, kelompok, organisasi, publik, dan massa) sangat penting membangun makna-makna yang sama terhadap setiap pesan yang berfungsi menumbuhkan integrasi dan solidaritas bangsa. 


\subsection{Perasangka Sosial}

Dalam istilah psikologi sosial, prasangka sosial merupakan sikap perasaan orang-orang terhadap golongan manusia tertentu, golongan ras, atau kebudayaan yang berlainan dengan kelompoknya. Prasangka sosial terdiri atas attitude-attitude sosial yang bersifat negatif terhadap golongan lain. Prasangka sosial memengaruhi tingkah laliu orang terhadap golongan manusia lain itu. Prasangka sosial lambat laun memunculkan sikap diskriminatif tanpa alasan-alasan objekktif (Gerungan, 1996:167).

Istilah prasangka (prejudice) berasal dari kata latin prejudicium, yang berarti suatu preseden, atau suatu penilaian berdasarkan keputusan dan pengalaman terdahulu (Allport 1954:6). Prasangka pada dasarnya cara pandang atau perilaku seseorang terhadap orang lain secara negatif. Itu sebabnya, prasangka sangat potensial menimbulkan kesalahpahaman ketimbang kesepahaman dalam berkomunikasi (Purwasito, 2003:178).

Terkait konsep itu, menurut Johnson (1986:356) prasangka yang didasari pada rasisme dan etnisitas erat dengan keberhasilan komunikasi sesama manusia. Prasangka, menurut Poortinga (1990:591), terdiri dari tiga faktor utama, yaitu: (1) stereotip; (2) jarak sosial; dan (3) diskriminasi itu berhubungan dengan efektivitas komunikasi; yang oleh Devito (1978:261) sangat tergantung dari faktor-faktor; (1) keterbukaan; (2) empati; (3) perasaan postif; (4) dukungan; dan (5) keseimbangan.

Lain halnya Alport (1954:6) yang berpendapat bahwa prasagka telah mengalami transformasi. Pada mulanya, prasangka merupakan pernyataan yang hanya didasarkan pada pengalaman dan keputusan yang tidak teruji terlebih dahulu. Pernyataan ini bergerak pada suatu skala suka tidak suka, mendukung tidak mendukung terhadap sifatsifat tertentu. Pengertian prasangka kini mengarah pada pandangan emosional dan bersifat negatif terhadap seseorang atau sekelompok orang tetentu.

Asumsi di atas tersimpulkan bahwa prasangka merupakan salah satu rintangan atau hambatan bagi suatu kegiatan komunikasi. Oleh karena itu orang-orang yang memunyai prasangka belum apa-apa sudah bersikap curiga dan menentang komunikator yang melakukan komunikasi. Dalam prasangka, emosi memaksa kita menarik kesimpulan atas dasar syakwasangka tanpa menggunakan pikiran dan pandangan kita terhadap fakta yang sebenarrnya. Andai seseorang sudah dihinggapi prasangka terhadap orang lain, maka apapun yang dilakukan orang itu akan diangganya negatif.

\subsection{Konsep Stereotip}

Hubungan antara prasangka dengan efektivitas komunikasi demikian eratnya karena prasangka (sebagai sikap yang umumnya negatif) menjadi dasar pembentuk komunikasi antarkelompok. Ketiga faktor tersebut dalam konsep komunikasi merupakan pesan-pesan yang dikirimkan oleh para komunikator dari setiap kelompok yang diduga memengaruhi efektivitas komunikasi dengan para komunikan dari kelompok lain.

Penelitian ini menekankan hubungan antarmanusia, yaitu hubungan antarpribadi dari komunikator dengan komunikan antarkelompok dalam situasi kelompok yang diwarnai oleh masingmasing visi dan misi kelompok. Hubungan itu mengikuti proses komunikasi yang terdiri dari sumber dan penerima (komunikator dan komunikan yang berasal dari kelompok-kelompok yang berbeda).

Dalam penelitian ini, istilah antarbudaya merupakan istilah yang banyak digunakan untuk menjelaskan interaksi, relasi, hubungan, komunikasi antara mereka yang berbeda latar belakang kebudayaannya, misalnya antarkelompok. Gudykunst dan Asante (1989:10), mengemukakan bahwa inti tema penelitian komunikasi antarbudaya adalah komunikasi antarpribadi diantara para anggota dari latar belakang budaya yang berbeda, apakah ras, kelompok etnik, atau golongan.

Beberapa studi yang berkaitan dengan tema hubungan antaretnik dari Bruner (1969); Schweizer (1983) dalam Mulyana dan Rakhmat, (1989); 
Pranowo dalam Soemarjan, 1988; Hstede dalam Mulyana dan Rakhmat, 1989; Pelly (1989); Riset yang dilakukan oleh Aloysius Liliweri, 1994 (disertasi) Komunikasi Antaretnik pada warga masyarakat Kupang, penelitian diarahkan kepada etnik-etnik yang ada di kota Kupang, bagaimana mereka saling berkomunikasinya; dan Sihabudin (1999) penelitian pada "Pendapat-Pendapat Antaretnik dikalangan mahasiswa Sunda, Batak, Minang dan Jawa di Jakarta.”

Kaitan konsep itu, konsep antaretnik dari David K Berlo dan Joseph DeVito. Mereka mengartikan komunikasi antarbudaya (baca: antaretnik) sebagai bentuk komunikasi antarpribadi dari komunkator dan komunikasi yang berbeda etniknya. Efektivitas komunikasi antarpribadi itu sangat ditentukan oleh faktor-faktor. keterbukaan, empati, perasaan positif, memberikan dukungan, dan memelihara keseimbangan. Sedangkan untuk prasangka (sosial) kajian ini menggunakan konsep Gordon Allport dan Poortinga yang menentukan tiga faktor utama prasangka, yaitu stereotif, jarak sosial, dan sikap diskriminatif.

Untuk variabel sikap diskriminasi antaretnik ditentukan oleh derajat penerimaan komunikator atas bentuk-benuk diskriminasi terhadap komunikan etnik lain. Misalnya,(1) mengurangi peranan komunikan; (2) menghalangi kemajuan; (3) menyingkirkannya; (4) meutasikannya dari suatu pekerjaan atau kedaerah lain; (5) membebaninya dengan tugas yang lebih berat; (6) memberikan dispensasi sebagai hukuman terselubung; (7) mendeskriditkan nama bainya; (8) tindak kekerasan fisik; (9)menekan psikologisnya; dan (10) menolak, membatasi, menutup peluang mendapatkan rezeki.

Hubungan antara prasangka dengan efektivitas komunikasi, sangat erat, karena prasangka diasumsikan sebagai dasar pembentuk perilaku komunikasi. Karena itu saya menjadikan hubungan antarkonsep ini sebagi paradigma untuk meneliti kondisi prasangka sosial dan efektivitas komunikasi antaretnik dalam suatu masyarakat majemuk seperti dialami orang Kupang. Paradigma tersebut merupakan simpulan dari (1) hasil kajian pelbagai teori (evolusi, etnosentrisme, prasangka, kebudayaan , komunikasi); dan (2) penelitianpeelitian terdahulu yang berkaitan dengan tema penelitian ini yang pada akhirnya menghasilkan 18 proposisi.

\subsection{Hipotesis}

Untuk menjawab pertanyaan penelitian maka saya mengemukakan suatu hipotesis umum/utama yang menjelaskan pengaruh prasangka sosial terhadap efektivitas komunikasi antaretnik.

(1) Jika seorang komunikator dari suatu etnik mempunyai pandangan semakin positif terhadap pesan-pesan tentang ciri-ciri dan sifat-sifat khas (stereotif) etnik lain;

(2) Semakin dekat pilihannya terhadap beragam bentuk interaksi sosial (jarak sosial) dengan etnik lain;

(3) Semakin kuat ia meolak pesan-pesan tentang bentuk diskriminasi (sikap diskriminasi) terhadap etnik lain maa sikapnya semain terbuka, empati, positif, mendukung dan memlihara kesimbangan dalam berkomunikasi dengan etnik lain.

\section{Metode Penelitian}

\subsection{Jenis Penelitian}

Jenis penelitian ini adalah survei, yang datanya dikumpulkan dari sampel sebagai contoh atas populasi. Penelitian ini bertujuan untuk menjelaskan hubungan, kontribusi, serta pengaruh antara variabel yang satu terhadap variabel yang lain melalui pengujian hipotesis. Dengan demikian, penelitian ini bersifat explanatory research.

\subsection{Operasionalisasi Variabel Penelitian}

Penelitian ini meliputi beberapa variabel, yaitu: (1) stereotip; (2) jarak sosial; (3) sikap diskriminasi (variabel bebas); dan (4) efektivitas komunikasi (variabel tidak bebas).

(1) Stereotip, yang dimaksud stereotip dalam penelitian ini adalah pesan yang berisi suatu pandangan, pendapat seorang komunikator dari suatu kelompok terhadap komunikan dari kelompok lain. Pandangan itu merupakan 
pesan yang berisi persepsi dan reaksi terhadap pesan-pesan tentang ciri-ciri dan sifat-sifat khas yang unik dari komunikan melalui perbandingan atraksi komunikator dan komunikan.

(2) Jarak Sosial, yang dimaksud jarak sosial dalam penelitian ini adalah pesan yang berisi derajat penerimaan seorang komunikator dari suatu kelompok terhadap komunikan dari kelompok lain dalam pelbagai bentuk interaksi sosial.

(3) Sikap Diskriminasi, yang dimaksud diskriminasi dalam penelitian ini adalah pesan dari seorang komunikator suatu kelompok tahap: pemisahan berdasarkan kelompok; pemindahan data dari daftar pertanyaan ke tabeltabel dalam buku kerja atau work sheet; pemeriksaan kelengkapan data yang telah dihitung skor akhir; dan pemindahan skor ke dalam tabel hasil penelitian dengan bantuan program komputer.

Pengujian hipotesis dilakukan dengan: distribusi frekuensi; analisis varians; korelasi; dan analisis regresi.

\section{Subhipotesis:}

(1) Semakin positif stereotip terhadap komunikan dari kelompok lain (Baduy dalam, Baduy Luar

\begin{tabular}{|l|l|}
\hline $\mathrm{X} 1=$ stereotip intrakelompok & $\mathrm{X} 2=$ stereotip antarkelompok \\
\hline $\mathrm{X} 3=$ jarak sosial intrakelompok & $\mathrm{X} 4=$ jarak sosial antarkelompok \\
\hline $\mathrm{X} 5=$ sikap diskriminasi intrakelompok & $\mathrm{X} 6=$ sikap diskriminasi antarkelompok \\
\hline $\begin{array}{c}\text { Y1 }=\text { efektivitas komunikasi } \\
\text { Intrakelompok }\end{array}$ & $\begin{array}{c}\mathrm{Y} 2=\text { efektivitas komunikasi } \\
\text { antarkelompok }\end{array}$ \\
\hline
\end{tabular}

tertentu terhadap komunikan dari kelompok lain tentang derajat penolakan penerapan bentuk-bentuk diskriminasi terhadap setiap komunikan kelompok lain.

(4) Efektivitas Komunikasi, yang dimaksud efektivitas komunikasi dalam penelitian ini adalah suasana kebathinan yang menyenangkan antara komunikator dari suatu kelompok dengan komunikan dari kelompok lain.

\subsection{Teknik Pengumpulan Data}

Data primer dikumpulkan melalui daftar pertanyaan berbentuk skala semantic differential. Tambahan informasi terhadap daftar pertanyaan yang telah dikumpulkan dilakukan melalui wawancara. Sedangkan data skunder yang berkaitan dengan variabel penelitian bersumber dari pustaka, rekaman, keterangan lisan dari pakar yang mengetahui tentang masalah yang diteliti.

\subsection{Teknik Analisis Data}

Data hasil penelitian diproses melalui tahap- dan Masyarakat Ciboleger) maka semakin efektif komunikasinya dengan mereka. Y2 $\mathrm{X} 2$

(2) Semakin dekat jarak sosial seseorang dengan kelompok lain (Baduy dalam, Baduy Luar dan Masyarakat Cibol eger) maka semakin efektif komunikasinyadengan merka Y2 X4.

(3) Semakin kuat seseorang menolak penerapan bentuk-bentuk diskriminas terhadap kelompok lain(Baduy dalam, Baduy Luar dan Masyarakat Ciboleger) maka semakin efektif komunikasinyadengan mereka. Y2 X6.

(4) Semakin positif pandangan stereotip antarkelompok, semakin dekat jarak sosial seseorang dengan kelompok lain (Baduy dalam, Baduy Luar dan Masyarakat Ciboleger) makasemakin efektif komuni kasinyamereka Y2 X2 X4.

(5) Semakin positif pandangan stereotip antarkelompok, semakin kuat seseorang menolak penerapan bentuk-bentuk diskriminasi terhadap kelompok lain (Baduy dalam, Baduy Luar dan Masyarakat Ciboleger), makasemakin efektif komunikasinyadengan 
mereka. Y2 X2 X6.

(6) Semakin dekat dan beragam seseorang memilih bentuk interaksi sosial dengan kelompok lain, semakin kuat ia menolak bentuk-bentuk diskriminasi terhadap kelompok lain (Baduy dalam, Baduy Luar dan Masyarakat Ciboleger), maka semakin efektif komunikasinya dengan kelompok lain. Y2 X4 X6

(7) Jika pandangan seseorang semakin positif tentang stereotip intrakelompok, dan antarkelompok maka komunikasi intrakelompok semakin efektif. Semakin efektif maka semakin efektif pula komunikasi dengan kelompok lain. Y2 Y1 X3 X4.

(9) Jika seseorang semakin kuat menolak bentukbentuk diskriminasi intrakelompok dan antarkelompok maka komunikasi intrakelompok semakin efektif. Semakin efektif komunikasi intrakelompok maka semakin efektif pula komunikasi dengan kelompok lain. Y2 Y1 X5 X6.

Rancangan riset dengan merujuk kepada hipotesis dapat dijelaskan melalui tahap-tahap pada gambar 1 .

Gambar 1.

(a) \begin{tabular}{ll|lllll} 
Y & 2 & X 2 & X 4 & X 6
\end{tabular}

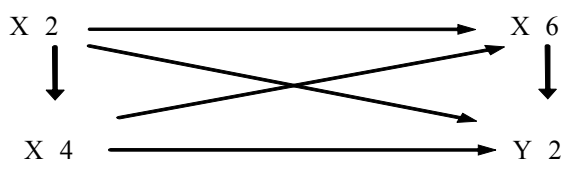

(b) \begin{tabular}{ll|llllll} 
Y & 2 & Y & 1 & X & 1 & X & 2
\end{tabular}

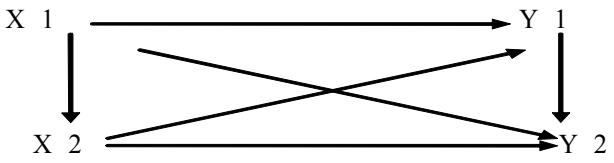

(c) \begin{tabular}{ll|lllllll} 
& $Y$ & 2 & $Y_{1}$ & 1 & $X_{3}$ & 3 & $X_{4}$ & 4
\end{tabular}

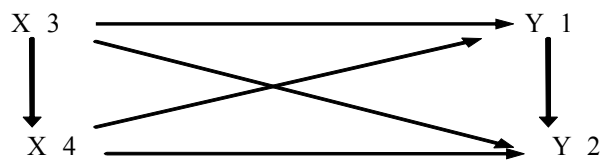

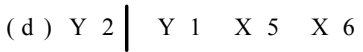

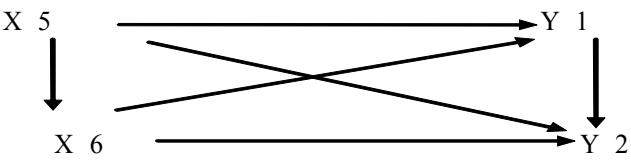

komunikasi intrakelompok maka semakin efektif pula komunikasi dengan kelompok lain. Y2 Y1 X1 X2.

(8) Jika pilihan terhadap bentuk-bentuk interaksi sosial dengan intrakelompok dan antarkelompok semakin mendekat maka komunikasi intrakelompok semakin efektif. Semakin efektif komunikasi intrakelompok

\subsection{Populasi dan Sampel}

Populasi adalah kelompok Suku Baduy Dalam, Suku Baduy Luar, dan Masyarakat Ciboleger. Ukuran sampel untuk penelitian ini pada dasarnya ditentukan oleh tipe pengujian hipotesis. Ada dua tipe pengujian, yaitu analisis regresi dan uji beda. Karena itu ukuran sampel dapat ditentukan 
Terakreditasi Dirjen Dikti SK No. 56/DIKTI/Kep/2005

berdasarkan korelasi dan perbedaan rata-rata.

Populasi penelitian ini heterogen sehingga perlu di bagi dalam subpopulasi yang lebih homogen, dengan membagi ke dalam 3 startum. Stratum Suku Baduy Dalam, Suku Baduy Luar, dan Masyarakat Ciboleger. Menurut Mendehal (1971: 54), metode penarikan sampel yang tepat adalah sampel acak berstrata (stratified random sampling).

\section{Hasil Penelitian dan Pembahasan}

\subsection{Analisis Hubungan Antar Variabel}

\subsubsection{Pendapat Orang Baduy Dalam terhadap Masyarakat Ciboleger}

Pengaruh Jarak Sosial $\left(\mathrm{X}_{1}\right)$ terhadap

Efektivitas Komunikasi ( $\left.\mathrm{Y}_{1}\right)$.

(a) Pengujian goodness offit Model dikatakan fit bilamana pengembangan model hipotetik secara konseptual dan teoritis didukung oleh data empirik. Uji goodness off fit adalah dengan mengetahui nilai cut off-nya antara lain: Nilai cut off RMSEA, $\mathrm{X}^{2}$, GFI dan AGFI (Solimun, 2002). Berdasarkan data yang telah diolah diperoleh RMSEA $<0,08, \mathrm{X}^{2}=\mathrm{p}>$ 0,05, GFI $>0,90$ dan AGFI $>0,90$ hal ini menunjukkan bahwa model tersebut adalah $f i t$ (baik). Artinya model tersebut layak diajukan untuk menduga hipotesis penelitian, sehingga model baik untuk digunakan menduga populasi. Dengan demikian model tersebut dapat digunakan sebagai landasan untuk merumuskan model keterikatan antara "jarak sosial dengan efektivitas komunikasi”.

(b) Pengujian model struktural

Pengujian model ini untuk mengetahui keakuratan model struktural dalam kaitannya dengan prediksi yang akan dilakukan dapat diperiksa melalui koefisien determinan total $\left(\mathrm{R}^{2}\right)$. Seperti dalam analisis regresi, nilai $\mathrm{R}^{2}$ berkisar antara 0 sampai dengan 1 , dan model dikatakan baik bilamana nilainya besar (mendekati 1). Menurut Solimun (2002) bahwa nilai $\mathrm{R}^{2}$ dalam regresi tersebut mirip dengan GFI pada goodness of fit. Berdasarkan data yang diperoleh nilai $\mathrm{GFI}=0,99$, maka koefisien determinan $\left(\mathrm{R}^{2}\right)$ mendekati angka 1 . Berarti model struktural tersebut memiliki keakuratan dalam memprediksi suatu variabel oleh variabel lainnya.

Dengan demikian efektivitas komunikasi dapat diprediksi oleh jarak sosial, dengan kata lain perbedaan jarak sosial akan menentukan tingkat efektivitas komunikasi. Berdasarkan hasil pengolahan data diperoleh nilai g (gama) sebesar 0,63 artinya jarak social berpengaruh besar terhadap efektivitas komunikasi.

(c) Pengujian model pengukuran

Model pengukuran yang dimaksud adalah pemeriksaan mengenai reliabilitas dan veliditas intrumen.

Validitas instrumen menurut Masrun dalam Solimun (2002) menyatakan bahwa bilamana koefisien korelasi antara skor suatu indikator dengan skor total seluruh indikator lebih besar $0,3\left(\mathrm{r}^{3} 0,3\right)$, maka instrumen tersebut dianggap valid. Dalam SEM besar kecilnya tingkat validitas setiap indikator (variabel manifest) dalam mengukur variabel laten ditunjukkan oleh besar kecilnya loading (1) pada analisis dengan data standardized. Dimana semakin besar 1 merupakan indikasi bahwa indikator yang bersangkutan semakin valid sebagai instrumen pengukur variabel laten tersebut.

Sedangkan pemeriksaan besar kecilnya tingkat reliabilitas setiap indikator dalam SEM ditunjukkan oleh nilai error (d delta untuk variabel exogen dan e epsilon untuk variabel endogen) pada analisis dengan data standardized. Reliabilitas tiap indikator $=1$ - $\mathrm{d}$ untuk variabel exogen dan $=1$ - e untuk variabel endogen. Semakin kecil nilai error, menunjukkan indikator tersebut memiliki reliabilitas yang tinggi sebagai instrumen pengukur variabel laten yang bersangkutan.

Berdasarkan hasil pengolahan data di peroleh nilai 1 (lamda) pada umumnya besar, baik pada variabel manifest untuk mengukur variabel laten jarak social maupun pada variabel manifest untuk mengukur variabel laten efektivitas komunikasi. Dengan demikian pada umumnya indikatorindikator tersebut adalah valid. Sedangkan nilai d 
(delta) dan e (epsilon) untuk variabel exogen (jarak sosial) maupun variabel endogen (efektivitas komunikasi) pada umumnya relatif kecil, jadi dapat dinyatakan bahwa setiap indikator pada variabel exogen (jarak sosial) maupun variabel endogen (efektifitas komunikasi) adalah reliable.

Berdasarkan uraian di atas, dapat dikemukakan bahwa jarak sosial pada masyarakat Baduy Dalam sangat menentukan terhadap efektivitas komunikasi dengan masyarakat Ciboleger. Artinya semakin jauh jarak social masyarakat Baduy Dalam, maka semakin tidak efektif berkomunikasi dengan masyarakat Ciboleger, sebaliknya semakin pendek jarak sosial masyarakat Baduy Dalam, maka semakin efektifberkomunikasi dengan masyarakat Ciboleger.

2. Pengaruh Bentuk-bentuk Diskriminasi $\left(\mathrm{X}_{2}\right)$ terhadap Efektivitas Komunikasi ( $\left.\mathrm{Y}_{1}\right)$

(a) Pengujian goodness of fit

Berdasarkan data yang telah diolah diperoleh RMSEA $=0,00<0,08$, dan p-value $=0,9977>$ 0,05 berarti bahwa model tersebut memenuhi syarat goodness of fit. Jadi rumusan model kaitan antara variabel bentuk-bentuk diskriminasi dengan variabel efektivitas komunikasi layak diajukan untuk menduga hipotesis penelitian, yang selanjutnya dapat dilakukan generalisasi terhadap populasi. Model tersebut dapat digunakan untuk mengetahui pengaruh variabel bentuk-bentuk diskriminasi $\left(\mathrm{X}_{2}\right)$ terhadap variabel efektivitas komunikasi $\left(\mathrm{Y}_{1}\right)$.

(b) Pengujian model struktural

Memperhatikan hasil pengolahan data diperoleh GFI sebesar 0,83 berarti koefisien determinan total $\left(\mathrm{R}^{2}\right)$ relatif mendekati angka 1, maka model tersebut dapat dikatakan baik. Hal ini menunjukkan bahwa model ini memiliki keakuratan dalam memprediksi suatu variabel oleh variabel lainnya.

Dengan demikian, koefisien determinan total $\left(\mathrm{R}^{2}\right)$ adalah 0,83 artinya variabel efektivitas komunikasi dapat diprediksi oleh variabel bentuk-bentuk diskriminasi. Dengan kata lain perubahan bentuk-bentuk diskriminasi akan mengubah tingkat efektivitas komunikasi. Namun demikian dari hasil pengolahan data diperoleh nilai g (gama) sebesar 0,03 artinya bentuk-bentuk diskriminasi pengaruhnya sangat kecil sekali terhadap efektivitas komunikasi. Angka ini dapat diabaikan, artinya hampir tidak ada pengaruh bentuk-bentuk diskriminasi terhadap efektivitas komunikasi, walaupun berpeluang untuk memengaruhi.

\section{(c) Pengujian model pengukuran}

Besar kecilnya 1 (lamda) pada analisis dengan data standardized menentukan besar kecilnya tingkat validitas setiap indikator (variabel manifest) dalam mengukur variabel laten. Jika nilai 1 besar berarti indikator tersebut semakin valid sebagai instrumen pengukur variabel laten. Dalam hal ini variabel bentuk-bentuk diskriminasi dan variabel efektivitas komunikasi.

Tingkat reliabilitas setiap indikator diketahui dengan melihat nilai error (delta) dan (epsilon) pada analisis dengan data standardized. Jika nilai error kecil berarti indikator tersebut tingkat reliabilitasnya tinggi dalam pengukur variabel laten.

Menurut data yang diolah di peroleh 1 (lamda) yang sebagian besar nilainya tinggi, baik pada variabel manifest untuk mengukur variabel laten bentuk-bentuk diskriminasi maupun pada variabel manifest untuk mengukur variabel laten efektivitas komunikasi. Hal ini berarti indikator-indikator tersebut sebagian besar adalah valid. Begitu juga nilai d (delta) dan e (epsilon) untuk variabel bentukbentuk diskriminasi maupun variabel efektivitas komunikasi, sebagian besar nilai relatif kecil, sehingga dapat dikatakan indikator-indikator tersebut adalah reliable, baik pada variabel laten bentuk-bentuk diskriminasi maupun pada variabel laten efektivitas komunikasi.

Memperhatikan uraian di atas, dapat dijelaskan bahwa bentuk-bentuk diskriminasi pada masyarakat Baduy Dalam tidak menentukan efektifitas komunikasi dengan masyarakat Ciboleger. Artinya bentuk-bentuk diskriminasi apapun pada masyarakat Baduy Dalam, tidak mempengaruhi efektif tidaknya komunikasi dengan 
Terakreditasi Dirjen Dikti SK No. 56/DIKTI/Kep/2005

masyarakat Ciboleger. Dengan kata lain bentukbentuk diskriminasi pada masyarakat Baduy Dalam, tidak berkaitan dengan efektif tidaknya komunikasi dengan masyarakat Ciboleger. Dengan demikian antara variabel bentuk-bentuk diskriminasi pada masyarakat Baduy dan variabel efektivitas komunikasi dengan masyarakat Ciboleger sebenarnya terjadi hubungan yang bebas.

\subsection{Pendapat Orang Baduy Dalam terhadap Masyarakat Baduy Luar}

(1) Pengaruh Jarak Sosial $\left(\mathrm{X}_{1}\right)$ terhadap Efektivitas Komunikasi ( $\left.\mathrm{Y}_{1}\right)$

(a) Pengujian goodness of fit

Mengacu pada data yang telah diolah diperoleh $\mathrm{GFI}=0,95>0,90$; dan $\mathrm{AGFI}=0,93>0,90$ data ini menunjukkan bahwa model tersebut adalah fit (baik). Artinya model tersebut layak dan baik untuk digunakan dalam menduga populasi. Jadi model tersebut dapat dijadikan landasan untuk merumuskan keterkitan antara variabel jarak sosial dengan variabel efektivitas komunikasi.

(b) Pengujian model struktural

Data yang telah diolah diperoleh nilai $\mathrm{GFI}=0,95$, berarti koefisien determinan $\left(\mathrm{R}^{2}\right)$ mendekati angka 1. Artinya model struktural tersebut memiliki keakuratan dalam memprediksi suatu variabel oleh variabel lainnya.

Dengan demikian bila terjadi perubahan jarak sosial akan menentukan tingkat efektivitas komunikasi. Dengan kata lain adanya perbedaan jarak sosial dapat memengaruhi tingkat efektivitas komunikasi. Berdasarkan hasil pengolahan data diperoleh nilai g (gama) sebesar 0,43 artinya jarak sosial berpengaruh cukup besar terhadap efektivitas komunikasi.

(c) Pengujian model pengukuran

Berdasarkan hasil pengolahan data diperoleh nilai 1 (lamda), baik pada variabel manifest untuk mengukur variabel laten jarak sosial maupun pada variabel manifest untuk mengukur variabel laten efektivitas komunikasi umumnya di atas 0,3 ; hanya ada satu nilai 1 (lamda) yang nilainya kurang dari 0,3 yaitu $\mathrm{x}_{1}=0,27$, tetapi bila angka ini dibulatkan dapat menjadi 0,3 . jadi secara umumnya indikator-indikator tersebut adalah valid. Sedangkan nilai d (delta) dan e (epsilon) untuk variabel jarak sosial maupun variabel efektivitas komunikasi pada umumnya relatif kecil, berarti dapat dinyatakan bahwa setiap indikator pada kedua variabel laten tersebut adalah reliable.

Memerhatikan uraian di atas, dapat dijelaskan bahwa jarak sosial pada masyarakat Baduy Dalam cukup mempengaruhi terhadap efektivitas komunikasi dengan masyarakat Baduy Luar. Jadi bila jarak sosialnya jauh pada masyarakat Baduy Dalam, maka akan kurang efektifberkomunikasi dengan masyarakat Baduy Luar, sebaliknya semakin pendek jarak sosial pada masyarakat Baduy Dalam, maka cenderung akan semakin efektifberkomunikasi dengan masyarakat Badui Luar.

(2) Pengaruh Bentuk-bentuk diskriminasi $\left(\mathrm{X}_{2}\right)$ terhadap efektivitas komunikasi $\left(\mathrm{Y}_{1}\right)$

(a) Pengujian goodness of fit

Berdasarkan data yang telah diolah diperoleh RMSEA $=0,00<0,08$, dan $\mathrm{GFI}=0,97>0,90$ artinya model tersebut memenuhi syarat goodness of fit, maka rumusan model hubungan antara variabel bentuk-bentuk diskriminasi dengan variabel efektivitas komunikasi layak diajukan untuk dianalisis lebih lanjut guna menguji hipotesis, yang dapat menduga parameter populasi. Model tersebut dapat dipakai untuk mengetahui dampak variabel bentuk-bentuk diskriminasi $\left(\mathrm{X}_{2}\right)$ terhadap variabel efektivitas komunikasi $\left(\mathrm{Y}_{1}\right)$ (b)Pengujian model struktural

Hasil pengolahan data diperoleh GFI sebesar 0,97 berarti koefisien determinan total $\left(\mathrm{R}^{2}\right)$ sangat dekat dengan angka 1, maka model ini memiliki ketepatan dalam memprediksi suatu variabel. Jadi menurut data ini variabel efektivitas komunikasi dapat diprediksi oleh variabel bentuk-bentuk diskriminasi yang ada. Perubahan pada bentuk-bentuk diskriminasi akan mengubah tingkat efektivitas komunikasi.

Menurut data yang diolah diperoleh nilai $g$ (gama) dekat dengan angka 1 , berarti bentukbentuk diskriminasi sangat memengaruhi terhadap efektivitas komunikasi. Jadi adanya bentuk-bentuk diskriminasi pada masyarakat Baduy Dalam sangat 
berpengaruh besar terhadap efektivitas komunikasi pada masyarakat Baduy Luar.

Pengujian model pengukuran:

Menurut data yang diolah di peroleh 1 (lamda) pada variabel manifest yang digunakan untuk mengukur variabel laten exogen memang kecil kecil dan hanya ada satu yang nilainya di atas 0,3 , tetapi pada variabel manifest yang digunakan untuk untuk mengukur variabel laten endogen seluruhnya di atas 0,3 . Hal ini dapat dinyatakan bahwa indikator-indikator tersebut sebagian besar adalah valid. Sedangkan nilai d (delta) dan e (epsilon) untuk mengukur reliabilitas variabel bentukbentuk diskriminasi maupun variabel efektivitas komunikasi, sebagian besar nilai relatif kecil, berarti dapat dinyatakan bahwa indikator-indikator tersebut adalah reliable.

Menyimak analisis di atas, dapat dikemukakan bahwa bentuk-bentuk diskriminasi pada masyarakat Baduy Dalam sangat menentukan efektivitas komunikasi dengan masyarakat Baduy Luar. Dengan demikian adanya bentuk-bentuk diskriminasi pada masyarakat Baduy Dalam benarbenar dapat memengaruhi tingkat efektivitas komunikasi dengan masyarakat Baduy Luar.

\subsubsection{Pendapat Orang Baduy Luar terhadap Orang Baduy Dalam}

(1) Pengaruh Jarak Sosial $\left(X_{1}\right)$ terhadap Efektivitas Komunikasi ( $\left.\mathrm{Y}_{1}\right)$

(a) Pengujian goodness offit

Mengacu pada data yang telah diolah diperoleh $\mathrm{RMSEA}=0,00<0,08 \mathrm{DAN} \mathrm{GFI}=0,92$ $>0,90$ data ini menunjukkan bahwa model tersebut adalah fit (baik). Artinya model tersebut layak dan baik untuk digunakan dalam menduga populasi. Jadi model tersebut dapat dijadikan landasan untuk merumuskan keterkitan antara variabel jarak sosial dengan variabel efektivitas komunikasi.

(b) Pengujian model struktural

Data yang telah diolah diperoleh nilai GFI $=$ 0,92 berarti koefisien determinan $\left(\mathrm{R}^{2}\right)$ mendekati angka 1 . Artinya model struktural tersebut memiliki keakuratan dalam memprediksi variabel efektivitas komunikasi oleh variabel jarak sosial.

Dengan demikian bila terjadi perubahan jarak sosial akan menentukan tingkat efektivitas komunikasi. Berdasarkan hasil pengolahan data diperoleh nilai g (gama) yang sangat dengan 1 (satu), artinya jarak sosial sangat berpengaruh sekali terhadap efektivitas komunikasi.

(c) Pengujian model pengukuran

Hasil pengolahan data di peroleh nilai l (lamda) pada pengukuran variabel laten jarak social umumnya di atas 0,3 dan hanya $\mathrm{x}_{1}$ yang kurang dari 0,3 , sedangkan pada pengukuran variabel laten efektivitas komunikasi seluruhnyadi atas 0,3 . jadi secara umumnya indikator-indikator tersebut adalah valid. Sedangkan nilai d (delta) dan e(epsilon) secara umum nilainya kecil, baik pada variabel jarak sosial maupun variabel efektivitas komunikasi, jadi dapat dikatakan bahwa setiap indikator pada kedua variabel laten tersebut adalah reliable.

Uraian di atas menunjukkan bahwa nilai $g$ (gama) mendekati angka 1, berarti jarak sosial pada masyarakat Baduy Luar sangat berpengaruh terhadap efektivitas komunikasi dengan masyarakat Baduy Dalam. Jadi bila jarak sosialnya dekat pada masyarakat Baduy Luar, maka akan sangat efektif berkomunikasi dengan masyarakat Baduy Dalam.

(2) Pengaruh Bentuk-bentuk Diskriminasi $\left(\mathrm{X}_{2}\right)$ terhadap Efektivitas Komunikasi ( $\left.Y_{1}\right)$

(a) Pengujian goodness offit

Berdasarkan data yang telah diolah diperoleh RMSEA $=0,00<0,08, \mathrm{GFI}=0,99>0,90$ AFGI $=$ $0,99>0,90$ artinya model tersebut memenuhi syarat goodness of fit, maka rumusan model hubungan antara variabel bentuk-bentuk diskriminasi dengan variabel efektivitas komunikasi layak diajukan untuk dianalisis lebih lanjut guna menguji hipotesis, yang dapat menduga parameter populasi. Model tersebut dapat dipakai untuk mengetahui dampak variabel bentuk-bentuk diskriminasi $\left(\mathrm{X}_{2}\right)$ terhadap variabel efektivitas komunikasi $\left(\mathrm{Y}_{1}\right)$. 
Terakreditasi Dirjen Dikti SK No. 56/DIKTI/Kep/2005

(b) Pengujian model struktural

Hasil pengolahan data diperoleh GFI sebesar

0,99 berarti koefisien determinan total $\left(\mathrm{R}^{2}\right)$ sangat dekat dengan angka 1, maka model ini memiliki ketepatan dalam memprediksi suatu variabel oleh variabel lainnya.

Menurut data ini variabel efektifitas komunikasi dapat diprediksi oleh variabel bentuk-bentuk diskriminasi yang ada. Perubahan pada bentuk-bentuk diskriminasi akan mengubah tingkat efektivitas komunikasi. Hasil pengolahan data diperoleh nilai g (gama) sebesar 0,49 hal ini menunjukkan bahwa bentuk-bentuk diskriminasi pada masyarakat Baduy Luar cukup memengaruhi efektivitas komunikasi dengan masyarakat Baduy Dalam.

(c) Pengujian model pengukuran

Menurut data yang diolah di peroleh 1 (lamda) pada pengukuran variabel laten exogen memang kecil kecil dan hanya ada dua yang nilainya di atas 0,3 , tetapi pada pengukuran variabel laten endogen seluruhnya di atas 0,3 . Hal ini dapat dinyatakan bahwa indikatorindikator tersebut sebagian besar adalah valid. Selanjutnya, pengukuran reliabilitas dapat dilihat pada nilai d (delta) dan (epsilon) pada variabel bentuk-bentuk diskriminasi maupun variabel efektivitas komunikasi, sebagian besar nilai d (delta) dan (epsilon) tersebut relatif kecil, berarti menunjukkan bahwa indikator-indikator tersebut adalah reliable.

Berdasarkan uraian di atas, dapat dikemukakan bahwa bentuk-bentuk diskriminasi pada masyarakat Baduy Luar cukup memengaruhi efektivitas komunikasi dengan masyarakat Baduy Dalam. Artinya bentuk-bentuk diskriminasi yang ada pada masyarakat Baduy Luar memang dapat mempengaruhi tingkat efektivitas komunikasi dengan masyarakat Baduy Dalam, tetapi pengaruhnya tidak terlalu besar.

\subsubsection{Pendapat Orang Baduy Luar terhadap Orang Ciboleger}

(1) Pengaruh Jarak Sosial $\left(\mathrm{X}_{1}\right)$ terhadap Efektivitas Komunikasi ( $\left.\mathrm{Y}_{1}\right)$ (a) Pengujian goodness offit

Uji goodness off fit adalah untuk mengetahui apakah model terseebut fit (baik) atau tidak, dengan cara mengetahui nilai cut off-nya. Menurut data yang telah diolah dari variabel jarak sosial dan variabel efektivitas komunikasi diperoleh nilai $\mathrm{RMSEA}=0,00<0,08$ dan $\mathrm{GFI}=$ $0,91>0,90$, nilai cut off tersebut menunjukkan bahwa model yang dibangun adalah fit (baik), sehingga layak digunakan sebagai landasan untuk merumuskan model hubungan kausal antara jarak sosial dengan efektivitas komunikasi dan sekaligus menguji hipotesis penelitian tentang dua variabel tersebut.

(b) Pengujian model struktural

Pengujian ini untuk mengetahui keakuratan model struktural melalui koefisien determinan total $\left(\mathrm{R}^{2}\right)$, yang dalam uji goodness of fit diperoleh dari nilai GFI. Berdasarkan hasil pengolahan data diperoleh nilai $\mathrm{GFI}=0,99>$ 0,90 , yang menunjukkan koefisien determinan $\left(\mathrm{R}^{2}\right)$ mendekati angka 1. Berarti model struktural ini memiliki keakuratan dalam memprediksi variabel efektivitas komunikasi oleh variabel jarak sosial.

Berdasarkan hasil pengolahan data diperoleh nilai g (gama) sebesar 0,67 artinya jarak sosial berpengaruh besar terhadap efektivitas komunikasi.

(c) Pengujian model pengukuran

Hasil pengolahan data di peroleh nilai ( (lamda) pada variabel exogen pada umumnya di atas 0,3 , dan hanya ada dua indikator yaitu $\mathrm{x}_{3}$ dan $\mathrm{x}_{4}$ yang kurang dari 0,3 , sedangkan pada variabel endogen semua indikatornya di atas 0,3 . Hal ini berarti pengukuran variabel laten jarak social maupun pengukuran variabel laten efektifitas komunikasi pada umumnya indikator-indikator tersebut adalah valid. Sedangkan untuk mengetahui pengukuran reliabilitas dapat diketahui melalui nilai $\mathrm{d}$ (delta) untuk variabel exogen (jarak sosial) dan e (epsilon) untuk variabel endogen (efektivitas komunikasi), nilai-nilai delta dan epsilon tersebut pada umumnya relatif kecil, jadi dapat dinyatakan bahwa indikator pada variabel 
exogen maupun variabel endogen adalah reliable.

Menyimak uraian di atas, terutama nilai g (gama) sebesar 0,67, maka dapat dijelaskan bahwa jarak social pada masyarakat Baduy Luar memberikan pengaruh besar terhadap efektivitas komunikasi dengan masyarakat Ciboleger. Artinya semakin dekat jarak sosial masyarakat Baduy Luar, akan semakin efektif berkomunikasi dengan masyarakat Ciboleger, begitu juga sebaliknya.

2. Pengaruh Bentuk-bentuk diskriminasi $\left(\mathrm{X}_{2}\right)$ terhadap efektivitas komunikasi $\left(\mathrm{Y}_{1}\right)$

(a) Pengujian goodness of fit Menurut data yang telah diolah diperoleh RMSEA $=0,00<0,08$, dan $(\mathrm{GFI})=0.98>0,90$, artinya model tersebut memenuhi syarat goodness of fit. Jadi dapat merumuskan model hubungan kausal antara variabel bentukbentuk diskriminasi dengan variabel efektivitas komunikasi, sekaligus dapat diajukan untuk menguji hipotesis, guna membuktikan parameter populasi. Model tersebut dapat mengukur besarnya pengaruh variabel laten (bentukbentuk diskriminasi) terhadap variabel laten (efektivitas komunikasi).

(b) Pengujian model struktural Hasil pengolahan data diperoleh GFI sebesar 0,98 , berarti koefisien determinan total $\left(\mathrm{R}^{2}\right)$ mendekati angka 1, maka model tersebut dapat dikatakan fit. Hal ini menunjukkan bahwa model tersebut memiliki keakuratan dalam memprediksi suatu variabel endogen oleh variabel exsogen. Artinya variabel efektivitas komunikasi dapat diprediksi oleh variabel bentuk-bentuk diskriminasi.

Diperoleh nilai g (gama) dari hasil pengolahan data sebesar 0,67 , memperlihatkan bahwa variabel bentuk-bentuk diskriminasi berpengaruh besar terhadap variabel efektivitas komunikasi.

(c). Pengujian model pengukuran

Model pengukuran didasarkan pada besar kecilnya nilai 1 (lamda) untuk pengukuran validitas serta nilai d (delta) dan (epsilon) untuk pengukuran reliabilitas.

Hasil pengolahan data di peroleh nilai l (lamda) pada variabel exogen umumnya lebih besar dari 0,3 , walaupun masih ada tiga indikator yang kurang dari 0,3. Sedangkan pada variabel endogen seluruh indikator nilainya lebih besar dari 0,3. Berarti indikator-indikator tersebut sebagian besar adalah valid.

Selanjutnya nilai d (delta) dan e (epsilon) untuk uji reliablitas, terlihat bahwa sebagian besar nilai error tersebut adalah kecil, artinya dapat dikatakan bahwa indikator-indikator tersebut adalah reliable, baik pada variabel laten (bentuk-bentuk diskriminasi) maupun pada variabel laten (efektivitas komunikasi).

Berdasarkan uraian di atas, dapat dikemukakan bahwa variabel exogen (bentuk-bentuk diskriminasi) pada masyarakat Baduy Luar berpengaruh besar terhadap variabel endogen (efektivitas komunikasi dengan masyarakat Ciboleger). Adanya bentuk-bentuk diskriminasi pada masyarakat Baduy Luar berperan besar terhadap efektivitas komunikasi dengan masyarakat Ciboleger. Dengan kata lain terdapat hubungan yang tidak bebas antara variabel exogen dengan variabel endogen, yaitu bahwa efektivitas komunikasi dengan masyarakat Ciboleger benarbenar ditentukan oleh adanya bentuk-bentuk diskriminasi pada masyarakat Baduy Luar.

\subsubsection{Pendapat Orang Ciboleger terhadap Orang Baduy Dalam}

1. Pengaruh Jarak Sosial $\left(X_{1}\right)$ terhadap Efektivitas Komunikasi ( $\mathrm{Y}_{1}$ )

(a) Pengujian goodness of fit

Uji goodness off fit untuk mengetahui apakah model tersebut fit atau tidak? dengan melihat nilai cut off-nya, antara lain: Nilai cut off RMSEA dan GFI. Berdasarkan data yang telah diolah diperoleh nilai RMSEA $=0,00<0,08$ dan $\mathrm{GFI}=0,94>0,90$, nilai-nilai ini menunjukkan bahwa model tersebut adalah fit (baik). Model tersebut layak diajukan untuk menguji hipotesis penelitian dan menduga parameter populasi. Dalam hal ini model tersebut dapat 
Terakreditasi Dirjen Dikti SK No. 56/DIKTI/Kep/2005

digunakan sebagai landasan untuk merumuskan model hubungan kausal antara variabel jarak sosial dengan variabel efektivitas komunikasi.

(b) Pengujian model struktural Pengujian model ini didasarkan pada koefisien determinan total $\left(\mathrm{R}^{2}\right)$ yang nilainya berkisar antara 0 sampai dengan 1 . Model dikatakan baik bilamana nilainya mendekati 1 . Nilai $\mathrm{R}^{2}$ dalam goodness of fit adalah GFI. Menurut data yang diperoleh nilai $\mathrm{GFI}=0,94$, maka koefisien determinan $\left(\mathrm{R}^{2}\right)$ mendekati angka 1. Artinya model structural tersebut memiliki keakuratan dalam memprediksi suatu variabel.

Jadi dalam hal ini variabell efektivitas komunikasi dapat diprediksi oleh jarak sosial, dengan kata lain perbedaan jarak sosial akan menentukan tingkat efektivitas komunikasi. Dari hasil pengolahan data diperoleh nilai $g$ (gama) sebesar 0,80 artinya jarak sosial pengaruhnya sangat besar terhadap efektivitas komunikasi.

(c) Pengujian model pengukuran

Pengujian model pengukuran untuk mengetahui validitas dengan memeriksa besar kecilnya 1 (lamda), sedangkan untuk mengetahui reliabilitas alat ukur dengan memeriksa nilai error (d delta untuk variabel exogen dan e epsilon untuk variabel endogen) pada analisis dengan data standardized. Reliabilitas tiap indikator $=1-\mathrm{d}$ untuk variabel exogen dan $=1$ - e untuk variabel endogen. Semakin kecil nilai error, menunjukkan indikator tersebut memiliki reliabilitas yang tinggi sebagai instrumen pengukur variabel laten yang bersangkutan.

Hasil pengolahan data di peroleh nilai (lamda) pada indikator variabel exogen memang ada dua indikator yang nilainya kecil, tetapi untuk variabel endogen seluruh indikator nilainya di atas 0,3 . Hal ini menunjukkan bahwa indikator-indikator tersebut pada umumnya adalah valid. Sedangkan nilai (delta) untuk variabel exogen (jarak sosial) dan e (epsilon)) untuk variabel endogen (efektivitas komunikasi) pada umumnya nilainya relatif kecil, berarti dapat dikatakan bahwa sebagian besar indikator pada kedua variabel laten tersebut adalah reliable.

Menelaah uraian di atas, terutama dengan melihat nilai g (gama) sebesar 0,80 , dapat dikemukakan bahwa jarak sosial pada masyarakat Ciboleger sangat menentukan terhadap efektivitas komunikasi dengan masyarakat Baduy Dalam. Artinya, semakin dekat jarak sosial pada masyarakat Ciboleger, maka semakin efektif berkomunikasi dengan masyarakat Baduy Dalam.

2. Pengaruh Bentuk-bentuk diskriminasi $\left(\mathrm{X}_{2}\right)$ terhadap efektivitas komunikasi ( $\left.\mathrm{Y}_{1}\right)$

(a) Pengujian goodness offit

Berdasarkan data yang telah diolah diperoleh RMSEA $=0,00<0,08$, dan GFI $=0,97>0,90$ berarti bahwa model tersebut memenuhi syarat goodness of fit. Dengan demikian, rumusan model hubungan kausal antara variabel bentuk-bentuk diskriminasi dengan variabel efektivitas komunikasi layak untuk diajukan, kemudian dirumuskan hipotesis untuk dilakukan uji generalisasi terhadap populasi. Model tersebut dapat digunakan untuk mengetahui besarnya pengaruh variabel bentuk-bentuk diskriminasi terhadap variabel efektivitas komunikasi.

(b) Pengujian model struktural

Hasil pengolahan data diperoleh GFI sebesar 0,97 berarti koefisien determinan total $\left(\mathrm{R}^{2}\right)$ relatif mendekati angka 1, maka model tersebut dapat dikatakan fit (baik). Hal ini menunjukkan bahwa model tersebut memiliki keakuratan untuk memprediksi variabel efektivitas komunikasi berdasarkan variabel bentukbentuk diskriminasi.

Koefisien determinan total $\left(\mathrm{R}^{2}\right)$ sebesar 0,97 menunjukkan bahwa variabel efektivitas komunikasi dapat diprediksi oleh variabel bentuk-bentuk diskriminasi. Artinya perubahan bentuk-bentuk diskriminasi akan mengubah tingkat efektivitas komunikasi.

Berdasarkan hasil pengolahan data diperoleh nilai g (gama) sebesar 0,16 , menunjukkan bahwa meskipun variabel $\mathrm{x}_{2}$ dapat memprediksi variabel $y$, tetapi pengaruh variabel bentukbentuk diskriminasi sangat kecil sekali 
terhadap variabel efektivitas komunikasi. Angka ini sebenarnya dapat diabaikan, artinya hampir tidak ada pengaruh variabel bentukbentuk diskriminasi terhadap efektivitas komunikasi.

(c) Pengujian model pengukuran Hasil pengolahan data di peroleh 1 (lamda) pada pengukuran variabel bentuk-bentuk diskriminasi umumnya memeroleh nilai kecilkecil, tetapi pada pengukuran variabel efektivitas komunikasi seluruhnya di atas 0,3. Hal ini berarti indikator-indikator tersebut sebagian besar adalah valid.

Uji reliabilitas dengan melihat nilai d (delta) untuk variabel bentuk-bentuk diskriminasi dan e (epsilon) untuk variabel efektivitas komunikasi, sebagian besar nilai relatif kecil, sehingga dapat dikatakan indikator-indikator tersebut adalah reliable.

Memerhatikan nilai g (gama) sebesar 0,16 menunjukkan bahwa bentuk-bentuk diskriminasi pada masyarakat Ciboleger tidak menentukan efektivitas komunikasi dengan masyarakat Baduy Dalam. Artinya bentuk-bentuk diskriminasi apapun pada masyarakat Ciboleger, tidak memengaruhi efektifitas komunikasi dengan masyarakat Baduy Dalam. Dengan kata lain, bentuk-bentuk diskriminasi pada masyarakat Ciboleger tidak ada hubungan kausal dengan efektivitas komunikasi dengan masyarakat Baduy Dalam. Berarti kedua variabel tersebut terjadi kebebasan hubungan.

\subsubsection{Pendapat Orang Ciboleger terhadap Orang Baduy Luar}

1. Pengaruh Jarak Sosial $\left(X_{1}\right)$ terhadap Efektivitas Komunikasi ( $\mathrm{Y}_{1}$ )

(a) Pengujian goodness offit

Berdasarkan data yang diperoleh dari masyarakat Ciboleger dan Baduy Luar diperoleh nilai $\mathrm{RMSEA}=0,00<0,08 \mathrm{DAN} \mathrm{GFI}=$ $0.91>0,90$ data ini menunjukkan bahwa model tersebut adalah fit (baik). Artinya model tersebut dapat dijadikan landasan untuk merumuskan hubungan kausal antara variabel jarak sosial dengan variabel efektivitas komunikasi. model tersebut juga layak dan baik untuk digunakan dalam menduga hipotesis serta populasi penelitian.

(b) Pengujian model struktural

Nilai GFI sebesar 0,91 berarti koefisien determinan $\left(\mathrm{R}^{2}\right)$ mendekati angka 1. Artinya model struktural tersebut memiliki keakuratan dalam memprediksi variabel exogen (efektivitas komunikasi) oleh variabel endogen (jarak sosial). Artinya bila terjadi perubahan jarak social akan berpengaruh terhadap tingkat efektivitas komunikasi.

Menurut hasil pengolahan data diperoleh nilai g (gama) sebesar 0,72, angka ini termasuk besar. Artinya variabel exogen (jarak sosial) berpengaruh besar terhadap variabel endogen (efektivitas komunikasi).

(c) Pengujian model pengukuran

Diperoleh nilai 1 (lamda) pada pengukuran variabel laten jarak social maupun pada pengukuran variabel laten efektifitas komunikasi seluruhnya di atas 0,3. Jadi indikator-indikator tersebut seemuanya adalah valid. Sedangkan nilai d (delta) dan e (epsilon) secara umum nilainya kecil, baik pada variabel jarak sosial maupun variabel efektivitas komunikasi, dengan demikian menunjukkan bahwa indikator-indikator pada kedua variabel laten tersebut adalah reliable.

Berdasarkan pada nilai g (gama) sebesar 0,72, berarti jarak social pada masyarakat Ciboleger berpengaruh besar terhadap efektivitas komunikasi dengan masyarakat Baduy Luar. Jadi bila jarak sosialnya dekat dalam masyarakat Ciboleger, maka akan sangat efektif berkomunikasi dengan masyarakat Baduy Luar.

2. Pengaruh Bentuk-bentuk diskriminasi $\left(\mathrm{X}_{2}\right)$ terhadap efektivitas komunikasi $\left(\mathrm{Y}_{1}\right)$

(a) Pengujian goodness offit Hasil pengolahan data diperoleh RMSEA = $0,00<0,08$ dan $\mathrm{GFI}=0,93>0,90$ artinya model tersebut memenuhi syarat goodness of fit, dengan kata lain model tersebut fit (baik). Jadi rumusan model hubungan kausal antara variabel bentuk-bentuk diskriminasi dengan variabel efektivitas komunikasi layak diajukan 
Terakreditasi Dirjen Dikti SK No. 56/DIKTI/Kep/2005

untuk dianalisis lebih lanjut guna menguji hipotesis, yang dapat menduga parameter populasi. Model tersebut dapat dipakai untuk mengetahui dampak variabel exogen terhadap variabel endogen.

(b) Pengujian model struktural

Menurut pengolahan data diperoleh GFI sebesar 0,93, maka koefisien determinan total $\left(\mathrm{R}^{2}\right)$ mendekati angka 1 , berarti model ini memiliki ketepatan dalam memprediksi variabel efektivitas komunikasi melalui variabel bentukbentuk diskriminasi. Artinya perubahan pada bentuk-bentuk diskriminasi akan mengubah tingkat efektivitas komunikasi.

Hasil pengolahan data diperoleh nilai g (gama) sebesar 0,03. Angka ini sangat kecil maka sebenarnya dapat diabaikan. Jadi, bentukbentuk diskriminasi pada masyarakat Ciboleger pada hakekatnya tidak berpengaruh terhadap efektivitas berkomunikasi dengan masyarakat Baduy Luar.

(c) Pengujian model pengukuran

Model pengukuran ini untuk menguji validitas dan reliabilitas instrumen. Uji validitas dapat dilihat pada nilai 1 (lamda). Nilai lamda pada pengukuran variabel exogen memang nilainya kecil kecil dan hanya ada dua yang nilainya di atas 0,3 , tetapi pada pengukuran variabel endogen seluruhnya di atas 0,3 . Artinya indikator-indikator tersebut sebagian besar adalah valid. Selanjutnya, pengukuran reliabilitas dapat dilihat pada nilaid (delta) pada variabel bentuk-bentuk diskriminasi dan e (epsilon) pada variabel efektivitas komunikasi, sebagian besar nilai d (delta) dan e (epsilon) tersebut relatifkecil, berarti indikator-indikator tersebut pada umumnya adalah reliable.

Memerhatikan uraian di atas, terutama dengan melihat nilai g (gama) yang sangat kecil yaitu 0,03 , maka sebenarnya angka ini dapat diabaikan. Artinya, antara variabel exogen dan variabel endogen sebenarnya terjadi kebebasan hubungan. Jadi, variabel bentuk-bentuk diskriminasi tidak berpengaruh terhadap variabel efektivitas komunikasi. Dengan kata lain bentuk-bentuk diskriminasi pada masyarakat Ciboleger sama sekali tidak ada hubungan kausal dengan efektivitas berkomunikasi pada masyarakat Baduy Luar.

\section{Kesimpulan dan Saran}

\subsection{Kesimpulan}

Dari seluruh uraian laporan penelitian dapat kami simpulkan beberapa hal sebagai berikut:

Jarak sosial pada masyarakat Baduy Dalam sangat menentukan terhadap efektifitas komunikasi dengan masyarakat Ciboleger. Artinya, semakin jauh jarak sosial masyarakat Baduy Dalam, maka semakin tidak efektif berkomunikasi dengan masyarakat Ciboleger, sebaliknya semakin pendek jarak sosial masyarakat Baduy Dalam, maka semakin efektifberkomunikasi dengan masyarakat Ciboleger.

Bentuk-bentuk diskriminasi pada masyarakat Baduy Dalam tidak menentukan efektivitas komunikasi dengan masyarakat Ciboleger. Artinya, bentuk-bentuk diskriminasi apapun pada masyarakat Baduy Dalam, tidak mempengaruhi efektif tidaknya komunikasi dengan masyarakat Ciboleger. Dengan kata lain bentuk-bentuk diskriminasi pada masyarakat Baduy Dalam, tidak berkaitan dengan efektif tidaknya komunikasi dengan masyarakat Ciboleger. Dengan demikian antara variabel bentuk-bentuk diskriminasi pada masyarakat Baduy dan variabel efektivitas komunikasi dengan masyarakat Ciboleger sebenarnya terjadi hubungan yang bebas.

Jarak sosial pada masyarakat Baduy Dalam cukup memengaruhi terhadap efektivitas komunikasi dengan masyarakat Baduy Luar. Jadi bila jarak sosialnya jauh pada masyarakat Baduy Dalam, maka akan kurang efektif berkomunikasi dengan masyarakat Baduy Luar, sebaliknya semakin pendek jarak social pada masyarakat Baduy Dalam, maka cenderung akan semakin efektif berkomunikasi dengan masyarakat Baduy Luar.

Bentuk-bentuk diskriminasi pada masyarakat Baduy Dalam sangat menentukan efektivitas komunikasi dengan masyarakat Baduy Luar. Dengan demikian adanya bentuk-bentuk diskriminasi pada masyarakat Baduy Dalam benarbenar dapat memengaruhi tingkat efektivitas 
komunikasi dengan masyarakat Baduy Luar.

Jarak sosial pada masyarakat Baduy Luar sangat berpengaruh terhadap efektivitas komunikasi dengan masyarakat Baduy Dalam. Jadi bila jarak sosialnya dekat pada masyarakat Baduy Luar, maka akan sangat efektif berkomunikasi dengan masyarakat Baduy Dalam.

Berdasarkan uraian di atas, dapat dikemukakan bahwa bentuk-bentuk diskriminasi pada masyarakat Baduy Luar cukup memengaruhi efektifitas komunikasi dengan masyarakat Baduy Dalam. Artinya, bentuk-bentuk diskriminasi yang ada pada masyarakat Baduy Luar memang dapat memengaruhi tingkat efektivitas komunikasi dengan masyarakat Baduy Dalam, tetapi pengaruhnya tidak terlalu besar.

Jarak sosial pada masyarakat Baduy Luar memberikan pengaruh besar terhadap efektivitas komunikasi dengan masyarakat Ciboleger. Artinya, semakin dekat jarak sosial masyarakat Baduy Luar, akan semakin efektif berkomunikasi dengan masyarakat Ciboleger, begitu juga sebaliknya.

Variabel exogen (bentuk-bentuk diskriminasi) pada masyarakat Baduy Luar berpengaruh besar terhadap variabel endogen (efektivitas komunikasi dengan masyarakat Ciboleger). Adanya bentukbentuk diskriminasi pada masyarakat Baduy Luar berperan besar terhadap efektivitas komunikasi dengan masyarakat Ciboleger. Dengan kata lain terdapat hubungan yang tidak bebas antara variabel exogen dengan variabel endogen, yaitu bahwa efektivitas komunikasi dengan masyarakat Ciboleger benar-benar ditentukan oleh adanya bentuk-bentuk diskriminasi pada masyarakat Baduy Luar.

Jarak sosial pada masyarakat Ciboleger sangat menentukan terhadap efektivitas komunikasi dengan masyarakat Baduy Dalam. Artinya, semakin dekat jarak sosial pada masyarakat Ciboleger, maka semakin efektifberkomunikasi dengan masyarakat Baduy Dalam.

Bentuk-bentuk diskriminasi pada masyarakat Ciboleger tidak menentukan efektivitas komunikasi dengan masyarakat Baduy Dalam. Artinya bentukbentuk diskriminasi apapun pada masyarakat Ciboleger, tidak mempengaruhi efektivitas komunikasi dengan masyarakat Baduy Dalam. Dengan kata lain bentuk-bentuk diskriminasi pada masyarakat Ciboleger tidak ada hubungan kausal dengan efektivitas komunikasi dengan masyarakat Baduy Dalam. Berarti kedua variabel tersebut terjadi kebebasan hubungan.

Jarak sosial pada masyarakat Ciboleger berpengaruh besar terhadap efektivitas komunikasi dengan masyarakat Baduy Luar. Jadi bila jarak sosialnya dekat dalam masyarakat Ciboleger, maka akan sangat efektif berkomunikasi dengan masyarakat Baduy Luar.

Variabel exogen dan variabel endogen sebenarnya terjadi kebebasan hubungan. Jadi variabel bentuk-bentuk diskriminasi tidak berpengaruh terhadap variabel efektivitas komunikasi. Dengan kata lain bentuk-bentuk diskriminasi pada masyarakat Ciboleger sama sekali tidak ada hubungan kausal dengan efektivitas berkomunikasi pada masyarakat Baduy Luar.

\subsection{Saran}

Dapat kami sarankan yang berminat pada studi prasangka sosial untuk melihat aspek sistem nilai, yang berlaku dalam suatu komunitas bagaimana pengaruhnya terhadap efektivitas komunikasi antarkelompok.

\section{Daftar Pustaka}

DeVito, Joseph, A. 1998. Komunikasi Antar Manusia. edisi kelima. Alih bahasa: Agus Maulana. Jakarta: Profesional Book.

DeVito, Joseph, A. 1978. Communicology: An Introduction to the Study of Communication. New York: Harper \& Row Publishing.

Gudykunst, B William, dan Asante, Molefi Kate. 1989. Handbook of International \& Intercultural Communication. London: Sage Publications.

Johnson, G. Allan. 1986. Human Arrangements \& Introduction to Sociology. Sandiego: Harcourt Brace. Inc. 
Terakreditasi Dirjen Dikti SK No. 56/DIKTI/Kep/2005

Liliwery, Aloysius. 1994. Komunikasi Anteretnik (studi tentang prasangka sosial terhadap efektivitas komunikasi anteretnik pada warga kota Kupang, NTT). Disertasi. Bandung: Program Pascasarjana Universitas Padjadjaran.

Mendenhal, William. 1971. Elementry Survey Sampling. California: Wardworts Publishing. Inc.

Mulyana, Deddy, dan Rakhmat, Jalaluddin. 1990. Komunikasi Antarbudaya. Bandung: Rosdakarya.

Porter E Richard, dan Larry A, Samovar. 1976. Intercultural Communication a Reader. 4th editon. California: Wardworts Publishing. Inc.
Pelly, Usman. 1989. Pengukuran Intensitas Potensi Konflik dalam Masyarakat Majemuk dalam Potensi Konflik. Jakarta: CSIS.

Sihabudin, Ahmad. 1999. Pendapat-Pendapat Antaretnik di Kalangan Mahasiswa Jakarta, Studi pada Mahasiswa Jawa, Sunda, Batak, dan Minang. Jakarta: Biro Pemasyarakatan IPTEK. LIPI.

Soemardjan, Selo (ed.). 1988. Stereotip Etnik, Asimilasi, Integrasi Sosial. Jakarta: YIIS.

Zastrow, Charles. 1989. Understanding Human Behavior \& The Social Environment. Chicago: Nelson Hall. 
